\title{
What Hope for North Atlantic Right Whales?
}

\section{Randall Reeves}

In the early 1800 s the once abundant North Atlantic right whale was believed to be extinct. But by mid-century the species had been 'rediscovered', and hunting was resumed until 1918, when the whales were again in trouble. In 1935 all right whales became fully protected by an international convention, and in the 1950s the North Atlantic population was once again 'rediscovered'. Today, after nearly $\mathbf{5 0}$ years of protection and slow recovery, the author assesses the present status of the North Atlantic population. Surveys showed disappointing results until in 1980 a survey of the lower Bay of Fundy (prompted by the threat of an oil refinery being built there) revealed surprisingly high numbers. Another survey in 1981 , in which the author also took part, has shown the Grand Manan Island region to be a summer and autumn assembly site for at least several dozen of these endangered whales, including a number of cows and calves. This may be a key area for the North Atlantic right whale's survival.

Right whales Eubalaena were once abundant in temperate marine waters worldwide. But their regular presence near continental and some island coasts, together with their slow swimming speed and tendency to float after death, made them a most attractive target for early whalers; even before the introduction of modern whaling techniques in the late 19th century, they had been severely depleted over much of their range. Many investigators recognize 
more than one species of right whale. The North Atlantic population $E$. glacialis is believed to be separate from the whales designated $E$. australis in the southern hemisphere and those in the North Pacific, which are called either $E$. glacialis, E. sieboldii, or E. japonica.

\section{Status of Stocks}

The stock of at least 400 right whales that winters along the southern coast of Africa appears to be increasing at an annual rate of about 7 per cent. ${ }^{1,2}$ An Argentine wintering population has also shown some signs of recovery; ${ }^{3}$ more than 500 individuals in this population have been identified during the past decade, mainly using photographs of the distinctive 'callosities' on the whales' heads. ${ }^{4}$ Evidence of a sustained increase in numbers in parts of the South Pacific is less conclusive, but sightings over the past few years in several areas are encouraging - see, for example, recent IWC Progress Reports for Australia and New Zealand. ${ }^{5}$

The situation in the North Pacific, however, is grim in comparison. In the 1950s and 1960s Russian and Japanese whalers, operating under special scientific permits conferred by their respective governments, killed 23 right whales. ${ }^{6}{ }^{7} \mathrm{~A}$ few right whales are still known to be present around the Aleutians and in the Sea of Okhotsk, ${ }^{8}$ but population trends are not evident. ${ }^{9}$ On the American side, where right whales were once very common, ${ }^{10}$ there has been a dearth of sightings in the last 25 years. ${ }^{5}, 11,12,13$ In the North Atlantic, where right whales were thought for a time to have been extirpated, there are possible signs of slow recovery on the western side, ${ }^{14}$ but the survival of a viable stock on the European side remains in doubt. ${ }^{15,16,17}$

\section{Basque Hunting}

The Basques are generally regarded as pioneers of the whaling industry. ${ }^{18}$ As early as the 12th century they had a well established right whale fishery in the Bay of Biscay, and they are believed to have begun whaling many years before that ${ }^{17}$ By the middle of the 17 th century the right whale had become rare off the coasts of Spain and France, forcing the whalers to venture farther from home. As early as the 1570 s the enterprising Basques were making extended fishing and whaling voyages to the coasts of Labrador and Newfoundland, ${ }^{19}$ and they found a productive whaling ground in what they called the Grand Bay - now known as the Strait of Belle Isle, separating Labrador from Newfoundland. Some of the whales hunted there could have been bowheads Balaena mysticetus, but most of those taken in summer were probably right whales. ${ }^{20}$

From the early 15th to the 18 th century the Basques also hunted right whales in the seas around England and Iceland. ${ }^{17}$ Whaling off northern Norway may have begun as early as the 10th century. ${ }^{21}$ Norwegians still call the right whale Nordkaper, after the North Cape, where the species was heavily exploited in the late 16th and early 17 th centuries. ${ }^{22}$ It has been suggested, although by no means proved, that the early Dutch and English whale fisheries at Spitsbergen involved right whales as well as bowheads. ${ }^{23}$ European colonists in New England hunted whales, mainly right whales, almost from the moment the Mayflower landed in $1620 .{ }^{24}{ }^{25}$ By 1750 the pattern begun by the Basques in the Old World had been repeated in the New. Right whales were now scarce off North America, and the Yankee whaling empire, of necessity, grew to 
Table 1. Known Captures and attempted Captures of North Atlantic Right Whales since 1931.

$\begin{array}{llllc}\text { Year } & \text { Location } & \text { Description } & \text { Comments } & \text { Source } \\ 1935 & \text { East coast Florida } & \text { Female and calf } & \text { Shot by fisherman } & 30 \\ 1937 & \text { Newfoundland } & \text { One } & \text { Killed by whalers } & 42 \\ 1951 & \text { Newfoundland } & \text { One } & \text { Taken "in error" } & 42 \\ 1959 & \text { Madeira } & \text { One } & \text { Killed by whalers } & 43 \\ 1967 & \text { Madeira } & \text { Female and calf } & \text { Killed by whalers } & 44\end{array}$

encompass seas far removed from the New Englanders' own shores.

After about 1800 the few North Atlantic right whales that survived this extensive and protracted slaughter had a slight reprieve because 'for many years (they were) believed to be extinct'. ${ }^{21}$

But after mid-century their reappearance off North America, Iceland, and northern Europe led to a resumption of right whaling, and American shore whalers were able to make sporadic catches until 1918 when the last enterprise (on Long Island, NY) finally folded. ${ }^{26}$ Some Yankee sperm whalers visited ports along the south-east coast of the United States in winter, cruising near shore for right whales before returning to the pelagic sperm whale grounds with the onset of favorable weather. ${ }^{27}$ Between 1889 and 1908 Norwegian whalers managed to find and kill close to 80 right whales east of Iceland and around the Faroes, the Shetlands, and the Hebrides. ${ }^{28}$ Then the British continued this exploitation: 85 right whales were landed at Scottish and Irish whaling stations between 1908 and $1914 .^{29}$

\section{Legal Protection}

So it was none too soon when in 1929 the Norwegian government took the lead in declaring the right whale a protected species. Two years later, the first international Convention for the Regulation of Whaling (which did not take effect until 1935) accorded full protection to right whales, and all subsequent whaling agreements have honoured the need of right whales to be left alone. The International Whaling Commission, which meets annually to set quotas and evaluate the status of stocks, has consistently listed the right whale as a species protected from commercial whaling, and, since 1977, also from catching by 'aborigines' or contracting governments on behalf of 'aborigines'.

The accompanying table listing the few known captures of right whales in the North Atlantic since 1931 shows only 6-7 whale deaths (Table 1), and there is no reason to suspect that many unreported captures have been made or attempted. Few other populations of large whales have enjoyed a nearly 50 -year period of immunity from both commercial and subsistence hunting in the present century.

\section{Rediscovery}

It is not clear that anyone was really looking for right whales in the North Atlantic after the First World War. Six were taken near the British Isles between 1920 and 1924, and one off Norway in 1926, but their occurrence was rarely mentioned during the late $1920 \mathrm{~s}, 30 \mathrm{~s}$, and $40 \mathrm{~s}$. In the early $1950 \mathrm{~s}$ cetologists on the east coast of North America began to look with renewed interest at local whale populations, and the North Atlantic right whale was 'rediscovered'. Several sightings were reported off eastern Florida in $1950,{ }^{30}$ 
and more between 1953 and $1963{ }^{31}$ It looked as if a small wintering herd had managed to survive off the south-eastern United States. Calves observed occasionally proved that reproduction had not altogether ceased.

In 1955 two right whales were photographed in Cape Cod Bay. ${ }^{32}$ This led scientists at the Woods Hole Oceanographic Institution in Massachusetts to begin watching for right whales on a regular basis, and in the 25 years since, Watkins and Schevill have made many important observations of right whale biology and behaviour. ${ }^{33}{ }^{34}$ One distinctively marked female they watched for four consecutive years as she returned to Cape Cod waters. ${ }^{35}$ In the first year a single small calf was with her, and in the second year, the yearling was still with her. Again in the fourth year she had a calf with her, suggesting that the calving interval can be as long as three years and that calf dependence may continue into the second year. Watkins and Schevill have not tried to census right whales, and are reluctant to guess at the size of the population visiting Cape Cod waters. But on one day in April 1970 they observed 70-100 different right whales near Cape Cod. ${ }^{32}, 35$

\section{Recent Censuses}

While the work of Watkins and Schevill has been primarily basic research, two studies of a more applied character have taken place in New England during the past four years. Increased demand for hydrocarbon development on the continental shelf of North America has forced the US Department of the Interior's Bureau of Land Management (BLM) to seek assurance that living marine resources potentially affected by drilling and transport activities have at least been inventoried. Consequently, an attempt has been made to determine the status of whale, dolphin, and turtle populations so that changes resulting from the search for offshore oil and gas can be monitored.

The BLM-sponsored Cetacean and Turtle Assessment Program (CETAP) is based at the University of Rhode Island.$^{36}$ Its principal task is to determine the seasonal distribution and density of cetacean and turtle populations off the eastern United States, with emphasis on endangered species. Shelf waters between Cape Hatteras, North Carolina, and Cape Sable, Nova Scotia, have been sampled frequently by aerial survey since the programme began in October 1978.

From May 9 to 12 , 1979, I participated in a CETAP right whale census. ${ }^{37}$ Based on the findings of Watkins and Schevill, we expected right whales to be most concentrated in the New England region at this time. However, our intensive, co-ordinated search, employing no fewer than six chartered aircraft and five boats, as well as many volunteer observers on land and at sea, proved disappointing. We could account for only 21 right whales that we knew were different individuals, and they were all found between Cape Cod and Georges Bank. Subsequent efforts by CETAP to census the right whale population have been somewhat more productive. In August 1980 an aerial survey off the south-east coast of Nova Scotia yielded a one-day count of 46 individual right whales in a small area. ${ }^{38}$

In the summer of 1980 another cetacean inventory began, aimed only at the lower Bay of Fundy. The threat of a proposed oil refinery at Eastport, Maine, had prompted the US Department of Commerce's National Marine Fisheries Service to commission this survey, conducted by staff of the New England Aquarium in Boston, Mass. Transects were flown over the area on a bi-weekly 


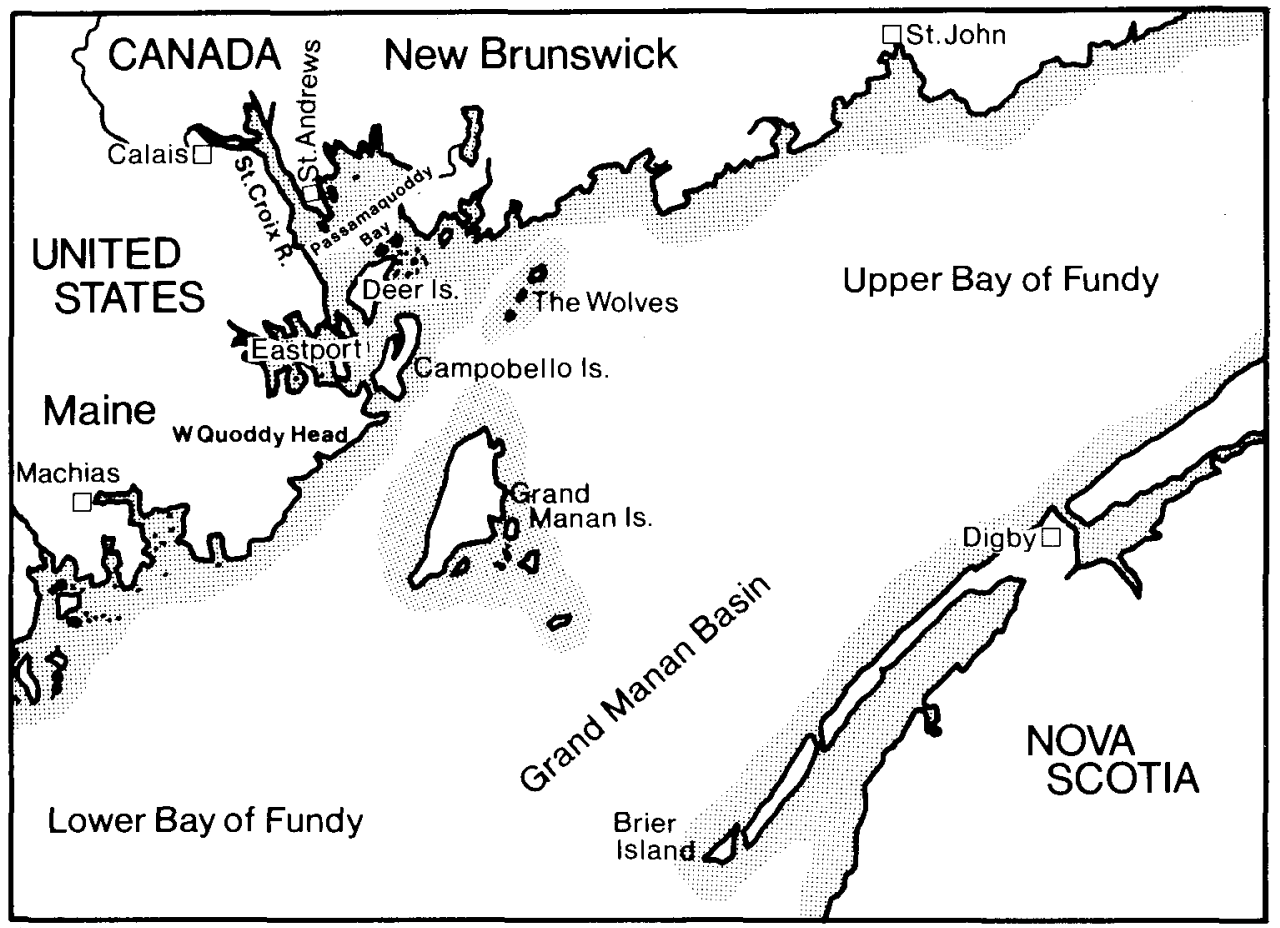

schedule to assess whale distribution and abundance..$^{39}$

BAY OF FUNDY

The Bay of Fundy was never an important whaling ground, and no serious scientific investigation of its large cetaceans had ever been made, but we had several good clues to what might be found there. A pod of 15 right whales had reportedly been seen in August 1966 from the Bluenose ferry as it crossed the bay between Bar Harbor, Maine, and Yarmouth, Nova Scotia, ${ }^{40}$ and in August 1971 a team from the University of Guelph, Ontario, had observed five right whales, including a calf, in the Deer Island area. ${ }^{41}$ Since then, occasional sightings had been reported in summer months, both there and near Brier and Grand Manan Islands.

We were nonetheless surprised at the number of right whales that turned up in our surveys in August and September. Within less than four hours on August 13, we counted 19 right whales in Grand Manan Basin and near the Wolf Islands, and analysis of our aerial photographs showing the distinctive configuration of 'callosities' on the whales' heads demonstrated that at least 26 different individuals were present in the study area between early July and October, including at least four cow-calf pairs. Our work in August and September 1981, consisting primarily of shipboard observation, resulted in photographic documentation of even more individuals.

\section{Factors Inhibiting Recovery}

A large amount of money and considerable human energy have been invested in efforts to count right whales in the western North Atlantic during the past four years, but the 70-100 animals seen in one day by Watkins and Schevill represent the best minimum estimate of population size. An optimistic view is that the population is simply too dispersed and mobile to be censused accurately, and that there are considerably more whales than the surveys have 
Table 2. Known Mortality of Right Whales in the Eastern United States, 1970-1979.

$\begin{array}{llllc}\text { Year } & \text { Location } & \text { Description } & \text { Comments } & \text { Source } \\ 1970 & \text { East coast Florida } & \text { Neonate } & \text { Stranded } & 45 \\ 1971 & \text { Long Island, N.Y. } & \text { One large } & \text { Stranded } & 46 \\ 1972 & \text { Freeport, Texas } & \text { One young } & \text { Stranded } & 47 \\ 1974 & \text { South Carolina } & \text { Male calf } & \text { Stranded } & 14 \\ 1975 & \text { Massachusetts } & 10.3 \mathrm{~m} \text { male } & \text { Stranded } & 14 \\ 1976 & \text { Massachusetts } & 7.6 \mathrm{~m} \text { male } & \text { Stranded } & 14 \\ 1976 & \text { Off Maine } & \text { One (i.d. uncertain) Floating dead } & 48 \\ 1979 & \text { Long Island, N.Y. } & \text { Young male } & \text { Stranded } & 49\end{array}$

demonstrated. Indeed, North Atlantic right whales are notoriously difficult to detect at times, and no one seems able to predict when or where concentrations of them will be encountered. A pessimistic view is that the population is either stable or decreasing slowly. However, it seems unlikely that it is declining, considering that 4 out of 26 , or about 15 per cent, of the whales we recognised as different individuals in the Bay of Fundy in summer 1980 were judged to be calves of the year. ${ }^{39}$ Known mortality, amounting to less than one whale per year in the last decade, does not seem excessive.

The vexing question is: what has prevented the North Atlantic right whale from making a more dramatic and convincing recovery after almost half a century of protection? Part of the answer may be simply that there were very few whales left when whaling stopped. Even with a net annual increase of seven per cent, such as has been estimated for South Africa's right whales, it would take a totally protected population of 20 individuals nearly 25 years to increase to 100 . Moreover, there could originally have been a number of geographically separate stocks, with little or no interchange, in the North Atlantic. The additional fragmentation caused by whaling may have led to the extirpation of some stocks (e.g. those in the Strait of Belle Isle and the Bay of Biscay and off Iceland and Finnmark) while seriously retarding the recovery of others. Factors such as competition for food with other baleen whales, collisions with ships, accidental fouling in fishing gear, and pollution have been brought forward to help explain the continuing scarcity of right whales. ${ }^{14}$

\section{The Vital Tranquility}

One of the best hypotheses, in my judgment, is that the combined effects of ship traffic, marine pollution, and coastal development in the North Atlantic have made formerly important breeding, nursing, and feeding grounds less habitable for right whales. The relatively unspoiled bays along the coasts of southern Africa and Argentina would appear, by contrast, to continue to provide the tranquillity that is in some way vital to the species.

If there is any truth in this, then the lower Bay of Fundy may be a key to the North Atlantic right whale's survival and recovery. Our observations in summer 1980 and again in 1981 suggest that the bay functions as a summering ground for right whales of all ages and both sexes. We have watched females interacting with their young calves, groups of as many as six or seven adults engaged in vigorous episodes of courtship, and lone individuals resting quietly at the surface or diving for periods of 10-15 minutes, presumably feeding. Their prolonged presence, spanning at least four months, from early July to 
the end of October, indicates that there may be something about the bay essential to right whale survival. We hope, in future field seasons, to learn more precisely why right whales come here and what can be done to ensure their continued unimpaired use of the bay.

There is plenty of reason to be cautious in assessing the right whale's status and prospects for survival in the North Atlantic. Far too little is known about their habitat requirements and the factors influencing their reproduction and mortality. Recovery to a 'safe' level still appears to be a long way off. Nevertheless, when compared to many endangered terrestrial species that continue to be hunted and whose habitat and food supplies are shrinking rapidly, the right whale's prospects seem encouraging.

\section{Acknowledgments}

I am grateful to Howard Winn and Richard Edel of the University of Rhode Island and to John Prescott and Scott Kraus of the New England Aquarium for enabling me to participate in their field studies of right whales. Also, Arthur Mansfield and Peter Best read the manuscript and offered helpful criticisms.

\section{References}

1. BEST. P.B. 1981. Rep. Int. Whal. Commn 31:

2. MERMOZ, J.F. 1980. Rep. Int. Whal. Commn 30: 183-186.

3. PAYNE, R.S., and E.M. DORSEY. 1979. pp. 46 in Abstracts from Presentations at the Third Biennial Conference on the Biology of Marine Mammals, Seattle, Wash.

4. CLARKE, R. 1965. Norsk Hvalfangst-tidende 1965. 6: 121-8.

5. GASKIN, D.E. 1972. Whales Dolphins and Seals, with special reference to the New Zealand region. Heinemann Ed. Books: London $200 \mathrm{pp}$.

6. KLUMOV, S.K. 1962. Trudy Inst. Okeanol. 58: 202-97. Russian, English abstract.

7. OMURA, H., et al. 1969. Sci. Rep. Whales Res. Inst. (Tokyo) 21: 1-78 + 18 plates.

8. BERZIN, A.A., and N.V. DOROSHENKO. 1981. Rep. Int. Whal. Commn 31:

9. RICE, D.W., and C.H. FISCUS. 1968. Norsk Hvalfangst-tidende 1968. 5: 105-107.

10. ROWNTREE, V., et al. 1980. Canadian F. Zool. 58: 309-312.

11. HERMAN, L.M., et al. 1980. Mar. Ecol. Prog. Ser. 2: 271-5.

12. REEVES, R.R., et al. 1978. Rep. Int. Whal. Commn 28: 303-12.

13. ANON. 1981. Rep. Int. Whal. Commn 31.

14. MARKHAM, C.R. 1881. Proc. Zool. Soc. Lond. 1881 : 969-76.

15. BARKAM, S. 1977. Geog. Mag. 49, 9: 574-81.

16. ESCHRICHT, D.F. and J. REINHARDT. 1866. pp. 3-150 in W.H. Flower (ed.), Recent Memoirs on the Cetacea. Ray Society: London.

17. HARMER, S.F. 1928. Proc. Linn. Soc. Lond. 140: 5195.

18. COLLETT, R. 1912. Norges Pattedyr. A. Aschehoug \& Co.: Kristiania. 744 pp.

19. GRAY, R.W. 1937. Naturalist 1937: 153-6.

20. ALLEN, G.M. 1916. Mem. Boston Soc. Nat. Hist. 8, 2, 105-322.

21. EDWARDS, E.J. and J.E. RATTRAY. 1932. "Whale off!": the story of American shore whaling. Fredrick A. Stokes Co.: New York. 285 pp.

22. COLLETT, R. 1909. Proc. Zool. Soc. Lond. 1909: 91, $8+3$ plates.

23. THOMPSON, D'A.W. 1918. Scott. Nat. 1918: 197-208.

24. MOORE, J.C. 1953. Amer. Mid. Nat. 49: 117-158.

25. LAYNE, J.N. 1965. Bull. Florida State Mus. (Biol. Sci) 9 4: 131-181.

26. WATKINS, W.A., and W.E. SCHEVILL. In press. Right whales (Eubalaena glacialis) in Cape Cod waters. F. Mammal.

27. WATKINS, W.A., and W.E. SCHEVILL. 1976. F. Mammal. 57: 58-66. 
28. WINN, H.E. 1979. Right whale sightings and the right whale minimum count. Quarterly summary of reports, Numbers 2 and 3 (combined). Submitted 31 July to Bureau of Land Management, CETAP, Univ. of Rhode Island, $62 \mathrm{pp}$. (unpubl. manuscript).

29. ANON. 1979. CETAP Newsletter. Univ. of Rhode Island. 4 pp.

30. KRAUS, S.D., and J.H. PRESCOTT. 1981. Distribution, abundance and notes on the large cetaceans of the Bay of Fundy summer and fall 1980. Final report to U.S.D.C., NOAA, National Marine Fisheries Service, Woods Hole, Mass. 66 pp. (unpubl. manuscript).

31. ARNOLD, P.W., and D.E. GASKIN. 972.F. Fish. Res. Bd. Canada 29: 1477-8.

32. SERGEANT, D.E. 1966. Populations of large whale species in the western North Atlantic with special reference to the fin whale. Fish. Res. Bd. Canada, Circular No. $9: 1-13+9$ tables +9 figures.

33. ANON., 1961. International Whaling Statistics XLV. Edited by The Committee for Whaling Statistics, Oslo. 87 pp.

34. MAUL, G.E., and D.E. SERGEANT. 1977. New cetacean records from Madeira. Bocagiana 43: 1-8.

35. CALDWELL, D.K., and M.C. CALDWELL. 1971. Cetology 4: 1-6.

36. SCHMIDLY, D.J., et al. 1972. Southwestern Naturalist 17, 2:214-5.

Randall R. Reeves, c/o Arctic Biological Station, 555 St. Pierre Boulevard, Ste-Anne-de-Bellevue, Quebec, Canada H9X 3R4.

\section{Gharial from Germany Brings Success}

Gharials Gavialis gangeticus have bred in captivity for the first time in the breeding station in Orissa, directed by Dr R.H. Bustard, one of the two stations in India established to save this highly endangered crocodile. The success was made possible by the Frankfurt Zoological Society which sent its male gharial - carried free by Air India because the male at Orissa was incapable of breeding. Of 25 eggs laid, 24 hatched.

The gharial project, which is supported by the Indian Government and aided by FAO/UNDP, has made great progress also with hatching and rearing gharial from eggs laid in the wild, and over 700 gharials have been released into specially declared wild sanctuaries in Orissa, Uttar and Madhya Pradesh and Rajasthan.

\section{A Part Dusky Seaside Sparrow?}

Only five males of the dusky seaside sparrow Ammodramus maritimus nigrescens survive in the world. They are in captivity at the Santa Fe Community College teaching zoo at Gainesville, Florida. Research has proved the feasibility of breeding these males with the closely related subspecies scotti of the Gulf Coast marshes. The researchers claim that a 94 per cent dusky could be developed in five generations, and by the third generation the offspring would be indistinguishable from duskies. However, the US Fish and Wildlife Service has refused to allow the Florida Audubon Society to conduct the last-ditch rescue operation. The reason? Because it would create a precedent and create an animal not covered by the Endangered Species Act!

\section{US Budget Cuts}

The Reagan administration has slashed all its environmental programmes. Endangered species grants are among the many features built up over the years, which once made the US the top environmental nation, that will almost or completely disappear. The Fish and Wildlife Service has been cut by $\$ 65.5 \mathrm{~m}$, and the Council on Environmental Quality loses 70 per cent of its funds. The clean lakes programme is among those axed. 